\title{
PENERAPAN SUPERVISI AKADEMIK UNTUK MENINGKATKAN KOMPETENSI GURU DALAM MENYUSUN RENCANA PELAKSANAAN PEMBELAJARAN HARIAN DI TK/PAUD SE-GUGUS 3 BAJAWA, KECAMATAN BAJAWA, KABUPATEN NGADA
}

\author{
Pulheria Meo Meka \\ Pengawas TK/ PAUD Kabupaten Ngada
}

\begin{abstract}
Tujuan penelitian ini adalah untuk meningkatkan kompetensi guru-guru TK/PAUD Gugus Bajawa 3, Kecamatan Bajawa dalam menyusun Rencana Pelaksanaan Pembelajaran Harian melalui pelaksanaan supervise akademik. Jenis penelitian yang digunakan dalam penelitian ini adalah penelitian tindakan sekolah. Kegiatan dalam penelitian ini terdiri atas tahapan perencanaan tindakan, pelaksanaan tindakan,observasi, dan refleksi. Penelitian ini dilakukan dalam dua siklus. Tempat penelitian di TK/PAUD Gugus Bajawa 3 , Kecamatan Bajawa, Kabupaten Ngada. Yang menjadi subyek dalam penelitian ini adalah guru - guru TKK/PAUD di Gugus Bajawa 3 yang berjumlah 13 orang, yang diambil dari 4 sekolah yang mewakili 7 sekolah yang ada di gugus Bajawa 3 . Teknik pengumpulan data menggunakan teknik waawancara, obeservasi kelas, dan diskusi. Analisis data yang digunakan adalah teknik analisis deskriptif komparatif. Data kuantitatif yang diperoleh dideskripsikan dalam bentuk kata-kata atau penjelasan. Selanjutnya dilakukan komparasi data untuk memastikan ada tidaknya peningkatan kemampuan guru dalam penilaian menyusun rencana pelaksanaan pembelajaran harian (RPPH). Dari ratarata nilai supervise akademik guru dalam menyusun RPPH pada kondisi awal diperoleh $62,61 \%$. Pada ahir Siklus I rata - rata nilai yang diperoleh $71,23 \%$, di akhir siklus II diperoleh $87,77 \%$, dan dari kondisi awal sampai dengan akhir siklus II nilai supervisi akademik meningkat sebesar 25,16\%. Hal ini dapat disimpulkan bahwa dengan Pelaksanaan Supervisi akademik, maka dapat meningkat kompetensi guru dalam menyusun RPPH di TK/PAUD Gugus Bajawa 3, Kecamatan Bajawa, TA 2018/2019
\end{abstract}

Kata kunci: supervisi akademik, rencana pelaksanaan pembelajaran harian, kompetensi guru

\section{PENDAHULUAN}

\begin{tabular}{lrlrr}
\multicolumn{2}{c}{ Pendidikan merupakan } & sumber daya manusia dapat \\
investasi dalam pengembangan & digolongkan & menjadi dua \\
sumber daya manusia dan & yaitu: tenaga kependidikan guru \\
dipandang sebagai kebutuhan & dan nonguru. Menurut Undang- \\
dasar bagi masyarakat yang ingin & Undang & Nomor \\
maju. Komponen-komponen sistem & 20 tahun 2003 tentang & Sistem \\
pendidikan yang mencakup & Pendidikan Nasional menyatakan,
\end{tabular}




\begin{abstract}
"komponen-komponen sistem pendidikan yang bersifat sumber daya manusia dapat digolongkan menjadi tenaga pendidik dan pengelola satuan pendidikan ( penilik, pengawas, peneliti dan pengembang pendidikan)." Tenaga gurulah yang mendapatkan perhatian lebih banyak di antara komponen-komponen sistem pendidikan. Besarnya perhatian terhadap guru antara lain dapat dilihat dari banyaknya kebijakan khusus seperti kenaikan tunjangan fungsional guru dan sertifikasi guru.
\end{abstract}

Pendidikan formal adalah jalur pendidikan yang terstruktur dan berjenjang yang terdiri atas pendidikan anak usia dini, pendidikan dasar, pendidikan menengah, dan pendidikan tinggi. Pendidikan formal terdiri dari pendidikan formal berstatus negeri dan pendidikan formal berstatus swasta

Taman Kanak-kanak adalah salah satu bentuk Pendidikan Anak Usia Dini pada jalur pendidikan formal yang menyelenggarakan program pendidikan bagi anak usia 4 - 6 tahun. Permendikbud Nomor 146 Tahun 2014 Tentang Kurikulum 13 PAUD digunakan sebagai pedoman penyelenggaraan proses kegiatan belajar mengajar untuk mencapai tujuan pendidikan. Metode pembelajaran dengan pendekatan bermain sambil belajar umum dan selalu diterapkan di Taman Kanakkanak. Melalui bermain anak dapat bereksplorasi, memperoleh dan memproses informasi belajar, halhal baru dan melatih keterampilan.

Pentingnya Pendidikan Anak Usia Dini, 4 - 6 tahun merupakan masa peka bagi anak. Anak mulai sensitif menerima berbagai upaya perkembangan seluruh potensi anak. Masa peka adalah masa terjadinya pematangan fungsifungsi fisik maupun psikis yang siap merespon stimulasi yang diberikan oleh lingkungan. Masa ini merupakan masa untuk meletakkan dasar pertama dalam pengembangan kemampuan fisik, kognitif, bahasa, sosial emosional, konsep diri, disiplin, kemandirian, moral dan nilai-nilai agama (Depdiknas, 2006)

Dalam UU NO. 20 TAHUN 2003 tentang Sistem Pendidikan Nasional Bab 1, Pasal 1, Butir 14 dinyatakan bahwa "Pendidikan Anak Usia Dini adalah suatu upaya pembinaan yang ditujukan kepada anak sejak lahir sampai dengan usia 6 tahun yang dilakukan melalui pemberian rangsangan pendidikan untuk membantu pertumbuhan dan perkembangan jasmani dan rohani agar anak memiliki kesiapan dalam memasuki pendidikan lebih lanjut". Sedangkan pada pasal 28 tentang Pendidikan Anak Usia Dini 
dinyatakan bahwa "(1) Pendidikan Anak usia dini diselenggarakan sebelum jenjang pendidikan dasar, (2) Pendidkan anak usia dini dapat diselenggarakan melalui jalur pendidkan formal, non formal, dan/atau informal, (3) Pendidikan anak usia dini jalur pendidikan formal: TK, RA, atau bentuk lain yang sederajat, (4) Pendidikan anak usia dini jalur pendidikan non formal: KB, TPA, atau bentuk lain yang sederajat, (5) Pendidikan usia dini jalur pendidikan informal: pendidikan keluarga atau pendidikan yang diselenggarakan oleh lingkungan, dan (6) Ketentuan mengenai pendidikan anak usia dini sebagaimana dimaksud dalam ayat (1), ayat (2), ayat (3), dan ayat (4) diatur lebih lanjut dengan peraturan pemerintah."

Pembelajaran dapat diartikan sebagai segala usaha atau proses kegitan belajar mengajar yang juga berperan dalam menentukan keberhasilan belajar siswa Dari proses pembelajaran itu akan terjadi sebuah timbal balik antara guru dan siswa untuk menuju tujuan yang lebih baik. Oleh karena itu pembelajaran di TK/PAUD berpedoman dan berprinsip pada belajar sambil bermain dan bermain seraya belajar, dengan menggunakan pedekatan tematik, dan berpusat pada anak. Proses Pembelajaran yang baik dimulai dari kesiapan gurunya dalam melaksanakan pembelajaran. Salah satunya adalah Penyiapan perangkat pembelajarn Harian yang akan digunakan sebagai pedoman guru dalam melaksanakan proses pembelajarn.

Philip Combs (dalam Kurniawati, 2009:66 ) menyatakan bahwa perencanaan program pembelajaran merupakan suatu penetapan yang memuat komponen-komponen

pembelajaran secara sistematis. Analisis sistematis merupakan proses perkembangan pendidikan yang akan mencapai tujuan pendidikan agar lebih efektif dan efisien disusun secara logis, rasional, sesuai dengan kebutuhan siswa, sekolah, dan daerah (masyarakat). Perencanaan program pembelajaran adalah hasil pemikiran, berupa keputusan yang akan dilaksanakan

Permendikbud No. 146 Tahun 2014 tentang Kurikulum 2013 PAUD memuat struktur kurikulum yang terdiri dari program - program pengembangan yang mencakup enam aspek perkembangan anak usia dini. Untuk itu "Rencana kegiatan harian (RPPH) adalah rencana yang menggambarkan prosedur dan pengorganisasian pembelajaran untuk mencapai satu kompetensi dasar yang ditetapkan dalam standar isi dan telah dijabarkan dalam silabus." yang 
komponennya harus memuat struktur kurikulum yang ditetapkan dalam Permen di atas.

Undang-Undang No. 14 tahun 2005 tentang Guru dan Dosen Pasal 4 menegaskan bahwa peran guru sebagai agen pembelajaran berfungsi untuk meningkatkan mutu pendidikan nasional. Untuk dapat melaksanakan fungsinya dengan baik, guru wajib untuk memiliki syarat tertentu, di antaranya adalah harus memiliki kualifikasi akademik dan kompetensi yang memadai serta motivasi kerja yang baik (Awe; 2014) . Kualifikasi Pengawas Taman Kanak- Kanak/ Raudhatul Athfal ( TK/RA) dan Sekolah Dasar/ Madrasah Ibtidaiyah adalah sebagai berikut.1) Berpendidikan minimum sarjana ( $\mathrm{S} 1$ ) atau diploma empat D-IV kependidikan dari perguruan tinggi terakreditasi. 2)Pengalaman kerja guru TK/RA minimal 4 tahun untuk menjadi pengawas. 3) Memiliki pangkat minimum piñata, golongan ruang III/C 4) Berusia setinggi-tingginya 50 tahun, sejak diangkat sebagai pengawas satuan pendidikan. 5) Memenuhi kompetensi pengawas melalui uji kompetensi ( seleksi pengawas).

Kompetensi guru adalah kemampuan atau kesanggupan guru dalam mengelola pembelajaran. Rusmini (2003) mengatakan bahwa titik tekan tentang kompetensi guru adalah kemampuan guru dalam pembelajaran bukanlah apa yang harus dipelajari (learning what to be learn). Dengan demikian, guru dituntut mampu menciptakan dan menggunakan keadaan positif untuk membawa mereka ke dalam pembelajaran agar anak dapat mengembangkan kompetensinya. Demikian juga halnya Untuk menyiapkan Rencana Perangkat Pembelajaran Harian yang baik guru diharapkan memiliki kompetensi yang baik, sehingga guru dapat menyiapkan perangkat pembelajaran dengan baik dan benar.

Rencana Pelaksanaan pembelajaran merupakan langkah yang sangat penting sebelum pelaksanaan pembelajaran. Permendikbud No. 146 Tahun 2014 tentang Kurikulum 2013 PAUD memuat struktur kurikulum yang terdiri dari program - program pengembangan yang mencakup enam aspek perkembangan anak usia dini. Untuk itu "Rencana kegiatan harian (RPPH) adalah rencana yang menggambarkan prosedur dan pengorganisasian pembelajaran untuk mencapai satu kompetensi dasar yang ditetapkan dalam standar isi dan telah dijabarkan dalam silabus." yang komponennya harus memuat struktur kurikulum yang ditetapkan dalam Permen di atas. 


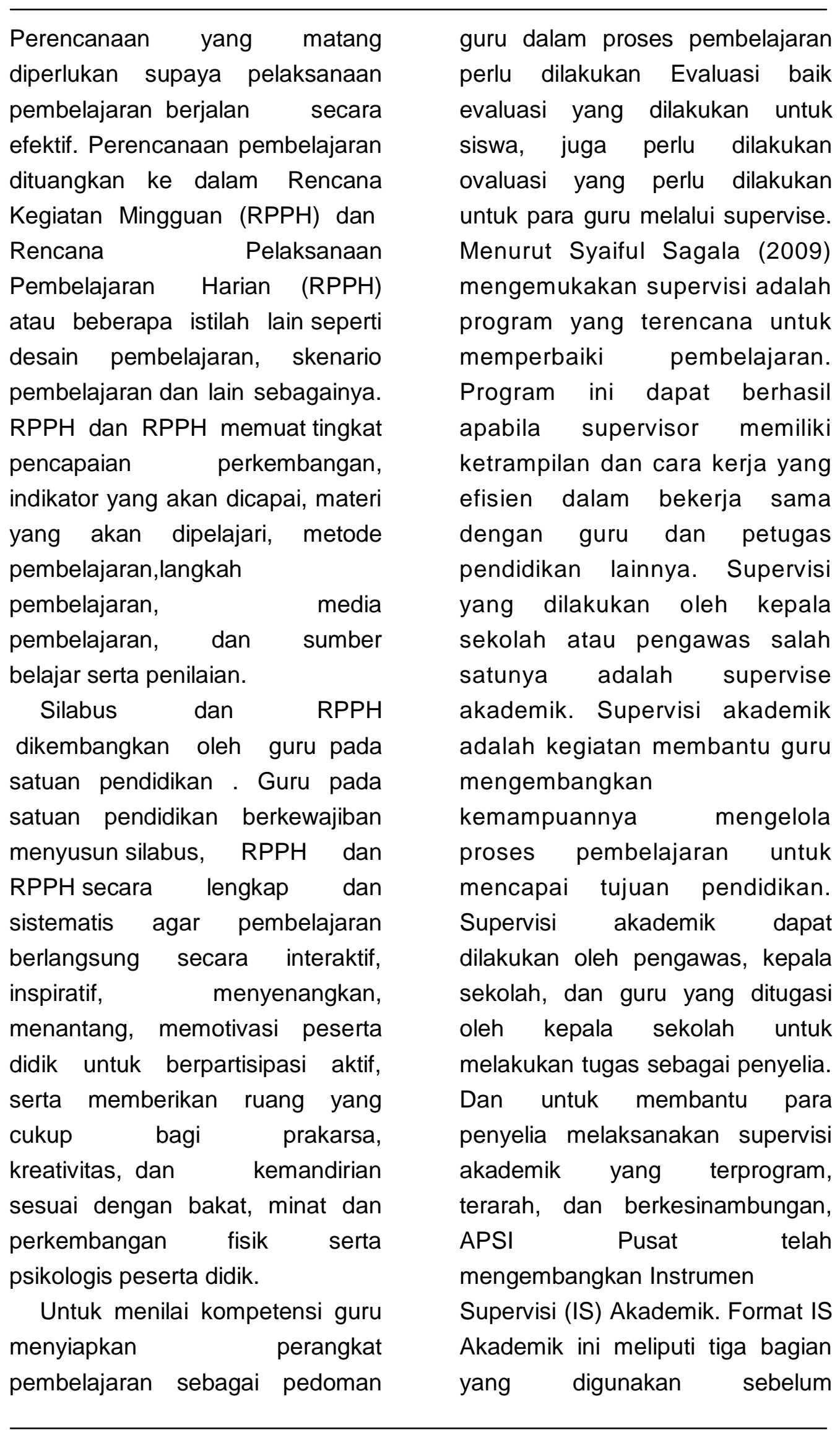




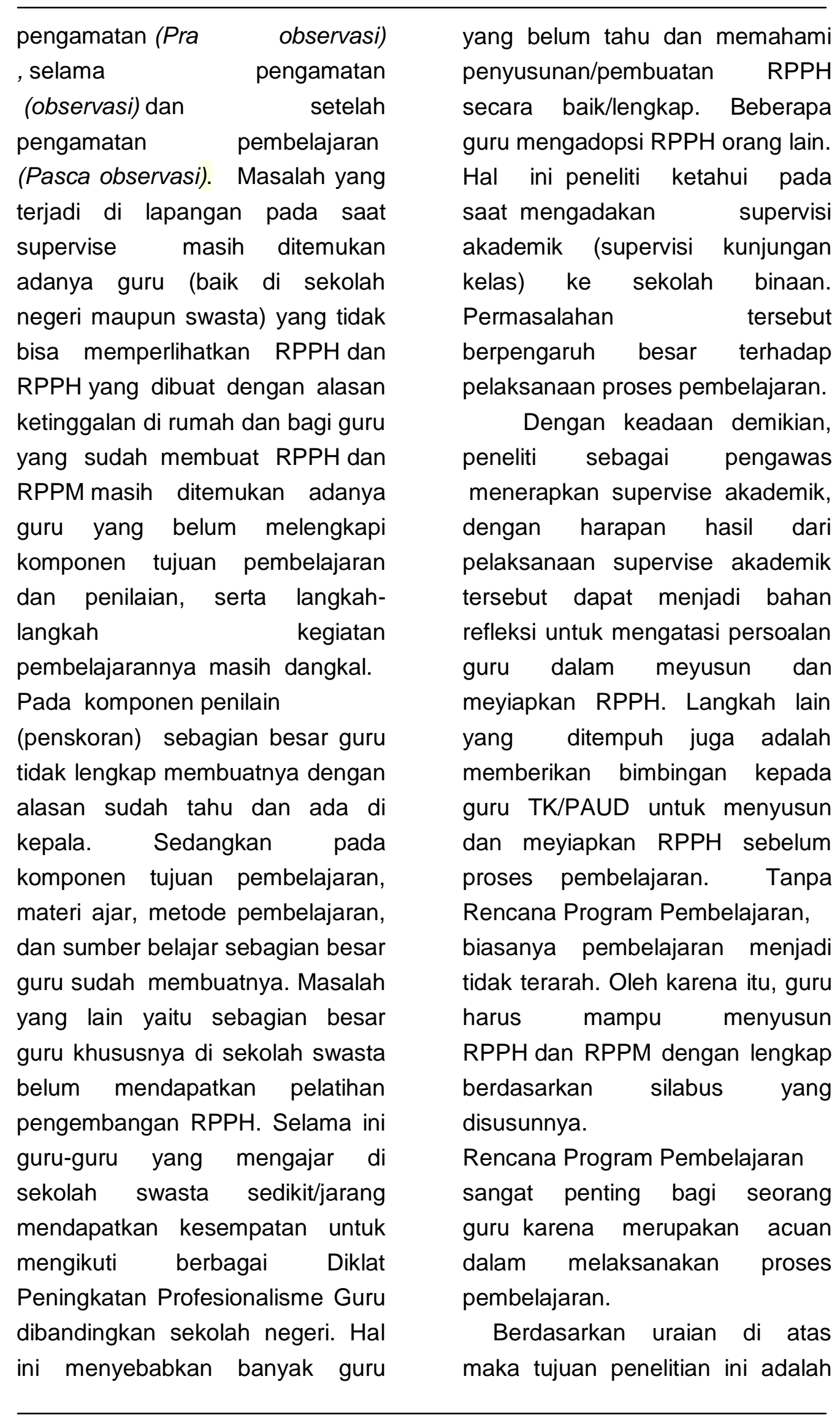




untuk mengetahui apakah
supervise akademik dapat
meningkatkan kompetensi guru
dalam menyusun rencana
pelaksanaan pembelajaran harian
di TK/PAUD se-Gugus Bajawa 3,
Kecamatan Bajawa, Kabupaten
Ngada.

\section{METODE PENELITIAN}

Jenis Penelitian ini adalah penelitian Tindakan kelas, dengan prosedur penelitian adalah, Perencanaaan, pelaksanaan, observasi, dan refleksi. Penelitian ini dilakukan dalam dua siklus. Subyek dalam PTS ini adalah guru - guru TK/ PAUD se- Gugus Bajawa 3, Kecamatan Bajawa, Kabupaten Ngada yang berjumlah 13 orang. PTS ini dilaksanakan selama kurang lebih tiga bulan mulai Agustus sampai dengan Oktober 2018. Teknik pengumpulan data menggunakan teknik wawancara, obeservasi kelas dan diskusi. Instrumen observasi yang digunakan adalah alat penilaian kompetensi guru (APKG) berupa: lembar observasi - Analisis data yang digunakan adalah teknik analisis deskriptif komparatif. Data kualitatif yang diperoleh dideskripsikan dalam bentuk kata-kata atau penjelasan. Selanjutnya dilakukan komparasi data untuk memastikan ada tidaknya peningkatan kemampuan guru dalam menyusun perencanaan pembelajaran, peningkatan kemampuan guru dalam pelaksanaan. Sebagai tolok ukur keberhasilan pelaksanaan penelitian tindakan sekolah ini ditetapkan indikator kinerja yaitu persentase jumlah skor perolehan kompetensi guru dalam menyusun rencana pelaksanaan pembelajaran harian sebesar $25 \%$.

$$
\mathrm{N}=\frac{\text { skor yang diperoleh }}{\text { skor maksimal }} \times 100
$$

Adapun kriteria penilaian yaitu: Baik Sekali berada di skor 91 sampai 100, Baik berada pada skor 76 sampai 90, Cukup berada pada skor 61 sampai 75, Kurang berada pada skor 51 sampai 60 sedangkan Kurang Sekali berada pada skor kurang dari 50 .

\section{HASIL PEMBAHASAN}

Berdasarkan hasil observasi peneliti terhadap RPPH yang dibuat guru pada kondisi awal , diperoleh informasi/data bahwa masih ada guru yang tidak melengkapi RPPH-nya dengan komponen dan sub-subkomponen RPPH tertentu, misalnya komponen indikator dan penilaian hasil belajar (pedoman penskoran). Rumusan kegiatan siswa pada komponen langkah-langkah kegiatan pembelajaran masih kurang tajam, interaktif, inspiratif, 
menantang, dan sistematis. Pada Kondisi awal ini peneliti belum menerapkan supervisi akademik secara ketat. Kegiatan supervisi masih lebih banyak dilakukan secara kelompok, dengan melalui diskusi dan memberikian motivasi kepada guru untuk menyiapkan dan membuat perangkat pembelajaeran secara baik. Melalui observasi dan pengamatan ini peneliti menmperoleh gambran bahwa hampir semua guru yang diamati menganggap bahwa RPPH itu belum bahkan bukan menjadi sebuah tuntutan dalam melaksanakan proses pembelajaran. Sehingga peneliti menganggap perlyu melakukan supervisi akademik yang diharapkan guru akan termotivasi dan membuat RPPH sebagai sebuah tuntutan dan kewajiban dalam melaksanakan proses pembelajaran. Adapun Nilai hasil supervisi akademik RPPH kondisi awal atau sebelum ada tindakan dari 13 orang guru dalam melaksanakan pembelajaran di kelas diperoleh nilai rata - rata guru dalam menyiapkan RPPH adalah $62,61 \%$. Dengan kondisi ini peneliti menerapkan Supervisi Akademik pada Siklus I.

Siklus pertama terdiri dari empat tahap yakni: (1) perencanaan, (2) pelaksanaan, (3) observasi, dan (4) refleksi .
Pada akhir observasi untuk evaluasi siklus I diketahui bahwa dari 13 guru secara umum ada perubahan lebih baik. Walaupun masih ada guru yang belum membuat komporen RPPH secara lengkap. Pada Tahap ini peneliti memberitahukan kekeliruan atau kekurangan yang dilakukan oleh setiap guru yang diobservasi dan menunjukkan dan membimbimbing bagaimana seharusnya membuat RPPH yang baik dan benar. Peneliti dalam hal ini sebagai Pengawas memberikan motivasi dan arahan dalam membuat $\mathrm{RPPH}$.

Hasil yang diperoleh pada Pelaksanaan Tindakan Siklus I, diketahui bahwa kompetensi guru TK/PAUD gugus 3 Bajawa dalam menyusun RPPH dari kondisi awal ke kondisi akhir siklus I mengalami peningkatan. Nilai rata-rata pada kondisi awal 62,61 \% meningkat menjadi $71,23 \%$ pada kondisi akhir siklus I. Berarti kompetensi guru-guru TK gugus 3 Bajawa dalam menyusun RPPH mengalami peningkatan dilihat dari rata-rata nilai siklus I sebesar $71,23 \%$, dibandingkan pada pra tindakan hanya nilai $62,61 \%$. Peneliti menggunakan pembinaan atau supervisi akademik pada siklus I. Model supervisi akademik yang digunakan supervise tradisional yang dilakukan secara kelompok dapat memotivasi guru 
dalam menyusun RPPH. Walaupun masih belum maksimal, namun setidaknya model supervisi ini, dilakukan dengan melalui prosedur yang sebenarnya. Dengan demikian hasil yang dicapai guru dalam observasi dan evaluasi menyusun RPPH dapat meningkat.

Hasil yang diperoleh pada pelaksanaan tindakan Siklus II, Kompetensi guru dalam meyusun RPPH diperoleh $87,77 \%$. Berarti kompetensi guru-guru TK/PAUD gugus 3 Bajawa dalam menyusun $\mathrm{RPPH}$ mengalami peningkatan sebesar 10,31\%. Hasil supervisi akademik dari kondisi awal dengan rata-rata nilai $62,61 \%$ ke akhir siklus I yang mencapai rata-rata nilai $71,23 \%$. Dari siklus I ke akhir siklus II juga ada peningkatan ratarata nilai hasil supervisi. Rata-rata nilai hasil supervisi pada siklus I adalah 71,23 \% menjadi 87,77\% di akhir siklus II. Dengan demikian dari kondisi awal ke kondisi akhir, rata-rata nilai kompetensi subjek penelitian mengalami peningkatan $25,16 \%$ Menurut data empirik penelitian tindakan sekolah sebagaimana tertulis di atas dapat disimpulkan bahwa melalui supervise akademik dapat meningkatkan kompetensi guru dalam menyusun RPPH di TK gugus 3 Bajawa, Kecamatan Bajawa.

Penelitian ini, peneliti memilih supervise akademik proses penyusunan RPPH. Dalam pandangan supervise akademik ini, membantu guru mengembangkan kompetensinya, mengembangkan kurikulum dan mengembangkan kelompok kerja guru dan membimbing penelitian tindakan kelas. Hasil tindakan supervisi memberikan gambaran peningkatan penyusunan RPPH. Skor capaian hasil penyusunan RPPH dari kondisi awal hingga akir siklus II tersebut dirangkum dalam tabel berikut.

Tabel 1 Komparasi Tingkat Kompetensi penyusunan $\mathrm{RPPH}$

\begin{tabular}{|l|c|c|}
\hline $\begin{array}{l}\text { Supervisi } \\
\text { Akademik }\end{array}$ & \multicolumn{2}{|l|}{$\begin{array}{l}\text { Tingkat } \\
\text { Kompetensi } \\
\text { penyusunan RPPH }\end{array}$} \\
\cline { 2 - 3 } & Mean & $\begin{array}{c}\% \\
\text { Kenaikan }\end{array}$ \\
\hline $\begin{array}{l}\text { Kondisi } \\
\text { Awal }\end{array}$ & 62,61 & - \\
\hline Siklus I & 71,23 & 8,62 \\
\hline Siklus II & 87,77 & 16,54 \\
\hline Peningkatan & & 25,16 \\
\hline
\end{tabular}

Dari data dalam tabel diatas, diperoleh temuan: a) pada kondisi awal, rata-rata tingkat kompetensi penyusunan administrasi penilaian pembelajaran baru mencapai 62,61 $\%$ (skor maksimal ideal 100); b) setelah diberikan tindakan, ratarata kompetensi penyusunan RPPH Siklus I mencapai 71,23 Siklus II $87,77 \%$. Data ini menunjukkan peningkatan kompetensi penyusunan RPPH Siklus I ke Siklus II sebesar 
16,54\%. Tabel berikutnya memberikan gambaran distribusi dan visualisasi skor kondisi awal dan setelah diberi tindakan.

Dari hasil penelitian tindakan sekolah ini terlihat bahwa kompetensi penyusunan RPPH mengalami peningkatan. Terlihat sudah tidak ada guru yang tidak membuat Rencana Pelaksanaan Pembelajaran harian, ada 1 guru (7,69 \%) pada kategori cukup, ada 9 guru $(69,23 \%)$ pada kategori baik, dan 3 guru $(23,08 \%)$ berada pada kategori sangat baik. Data pada tabel mengenai kompetensi guru pada kondisi awal dan tindakan menunjukkan temuan skor kemampuan guru dalam penyusunan administrasi penilaian pembelajaran kondisi awal $62,61 \%$ pada tindakan siklus II $87,77 \%$. Temuan ini mengindikasikan adanya peningkatan tingkat kemampuan guru dalam penyusunan RPPH. Besaran peningkatan 25,16\%. Jika dibandingkan dengan indikator kinerja $25 \%$ ternyata temuan tersebut telah mencapai keberhasilan

\section{PENUTUP}

Berdasarkan hasil penelitian tindakan sekolah dinyatakan berhasil. Terbukti dengan terpenuhinya indikator keberhasilan yang ditetapkan yaitu: 1) Melalui supervisi akademik dapat meningkatkan kompetensi guru dalam menyusun Rencana Pelaksanan Pembelajaran Harian. 2) Tindakan penelitian pada siklus I berhasil meningkatkan kompetensi guru dalam menyusun Rencana Pelaksanaan Pembelajaran Harian. Nilai rata-rata pada kondisi awal $62,61, \%$ meningkat menjadi $71,23 \%$ pada akhir siklus I. Perubahan teknik supervisi akademik pada siklus II lebih meningkatkan kompetensi guru dalam menyusun Rencana Pelaksanaan Pembelajaran sehingga nilai rata-ratanya $71,23 \%$ menjadi 87,77\%; 3) Pelaksanaan supervisi akademik yang dapat meningkatkan kompetensi guru dalam menyusun RPPHbagi guru TK gugus Bajawa 3 dengan menggunakan Alat Instrumen Observasi kegiatan pembelajaran. Dengan Supervisi akademik yang dilakukan secara berkesinambungan dan pemberian motivasi yang baik, serta bimbingan yang diberikan kepada guru dapat meningkatkan kompetensi guru TK/PAUD gugus 3 Bajawa dalam meyusun RPPH untuk kegiatan Pembelajaan. Hal ini terbukti secara empirik dalam penelitian ini yang dapat dilihat dari peningkatan dari kegiatan Pra Siklus, Siklus I dan sampai pada peningkatan Siklus ke II. Berdasarkan indikator yang ditetapkan dalam pelaksanaan 
Sudjana Nana dkk. 2011. Buku Kerja Pengawas Sekolah. Pusat Pengembangan

Tenaga Kependidikan, Badan PSDM dan PMP. Jakarta: Kementerian Pendidikan dan Kebudayaan
Suhertian, (2000). Konsep Dasar dan Teknik Supervisi Pendidikan.Jakarta: Rineka Cipta

------- 2009. Undang-Undang Nomor 39 tahun 2009 Tentang pemenuhan Beban Kerja Guru dan Pengawas Satuan Pendidikan. Jakarta 